\title{
アサクサノリの脂質組成とその抗酸化性について
}

\section{Component Lipids of Purple laver and their Antioxygenic Activity}

(昭 和 43 年 4 月 17 日受理)

\author{
安 藤 英 彦* 金 田 尚 志* \\ (Hidehiko Ando) (Takashi Kaneda)
}

Dried Purple laver, Porphyra tenera, is the favorite seaweed among Japanese. This seaweed contains a small per cent of lipids, and it is known that the component fatty acids of lipids consist mainly of highly unsaturated fatty acids. However, a rancid odor is not detectable during storage.

In order to determine the antioxygenic activities of purple laver, the lipids were fractionated and the activity of each fraction was tested. The whole lipids were extracted with chloroform-methanol mixture, and the lipids thus obtained were fractionated by silicic acid column chromatography with increasing concentration of ethyl ether in $\mathrm{n}$-hexane (Fig. 1). Phospholipids were separated in the same way but by the use of methanol-chloroform mixture (Fig. 2). Approximately 35 per cent of the whole lipids were phospholipids and 25 per cent were triglycerides. Upon analyzing fatty acids of each fraction by gas-liquid chromatography, it was clear that 40-55 per cent of fatty acids comprised $\mathrm{C}_{22}:_{3}$ acid. In particular, phospholipids were characteristically rich in $\mathrm{C}_{22}:$, acid (55\%).

According to the results of the comparison of the antioxygenic activity of each fraction, the whole lipids and the phospholipids fraction showed similar effect with BHT used as control; moreover, both of them showed the effect as synergist (Fig. 3 and 4 ).

\footnotetext{
アサクサノリに: $1.5 \%$ 2.0\%程度の脂質が含まれる が, 本脂質の脂肪酸は高度不飽和酸に富むことが知られ ている゙”。フサクサノリは薄く干しあげられているにも かかわらず脂質が関与する酸敗臭を感じない。また過酸 化物価を測定してみると，30前後であった。そこで筆者 らはアサクサノリ中に，含有脂質の酸敗を防此するよ5 な成分があるのではないかと思い，その㭘索を行なっ た。またアサクサノリ脂質についてての詳しい報告は出さ れていないので, 抗酸化性を検討する際, 脂質組成をみ たので、これらの結果を報告する。
}

\section{実験方法および結果}

脂溶性区分に存在すると思われる抗酸化成分を分別す るため以下のごとく脂質を抽出，分画した。

1. 試料

市販の乾海苔（上叙品）を用いた。

2. 総脂質の抽出

Olcot $\mathrm{t}^{2)}$ らの方法に染してて総脂質を抽出した。すなわ ち一定量の試料にクロロホルム：メタノール(2:1) 混液 3 倍量を加え，2 分間ブレンダーにかけホモジナイ
ズし，さらに 1 倍量のクロロホルム扰よび本を加えて1 分間ホモジナイズをくりかえした。ホモジナイズしたす のは口過し，組䋘の残渣を 1 倍量のクロロホルムで再び 抽出口過を行ない, 口夜のクロロホルムは合わし, 減圧 濃縮し総脂質を得た。得られた総脂質は乾燥アサクサノ リに対し $1.7 \%$ \%むった。

3. ケイ酸カラムクロマトグラフィーによる脂質の分 画

フサクサノリから抽出した総脂質をケイ酸カラムクロ マトグラフィー2゙により分別を行なった。使用した溶剤 は Table 1 のとおりである。結果はTable 1 およで Fig 1に示した。各溶出物は T.L.C. および P.C. ${ }^{3)}$ による 磼認を行なった。

\section{4. リン脂質の検索}

前訊験で得られたりン脂質をケイ酸カラムクロマトグ ラフィーにより分画した。すなわちFig. 2 に示すごとく クロロホルム・メタノール混合溶媒中のメタノールの割 合を $3,12,18,25,33,50,85,100$ と順に增してゆ きリン脂質を溶出分別した。溶出曲線は HARRIS‘) 法 によりPを定量して画いた。各画分は T.L.C.により単 一スポットを得た (Table 2)。クロロホルム・メタノー 


\section{栄湌と食粗}

Table 1. Stepwise elution of lipids of dried purple laver with silicic acid column

\begin{tabular}{l|r|l|r}
\hline \multicolumn{1}{c|}{ Solve nt } & $\mathrm{ml}$ & \multicolumn{1}{|c}{ Lipid class } & Yield (\%) \\
\hline$n$-Hexane & 100 & Hydrocarbons & 12.1 \\
$3 \% \mathrm{Et}_{2} \mathrm{O}$ in $n$-hexane & 200 & Sterolesters & 2.4 \\
$15 \% \mathrm{Et}_{2} \mathrm{O}$ in $n$-hexane & 250 & Triglycerides & 25.1 \\
$30 \% \mathrm{Et}_{2} \mathrm{O}$ in $n$-hexane & 250 & Sterols, Diglycerides, Chlorophyll & 11.9 \\
$\mathrm{Et}{ }_{2} \mathrm{O}$ & 250 & F. A., Monoglycerides, Xanthophylls & 13.4 \\
$\mathrm{MeOH}$ & 200 & Phospholipids & 35.1 \\
\hline
\end{tabular}

Fig. 1. Separation of dried purple laver-lipids by stepwise elution from silicic acid column with increasing concentrations of ethyl ether in $n$-hexane

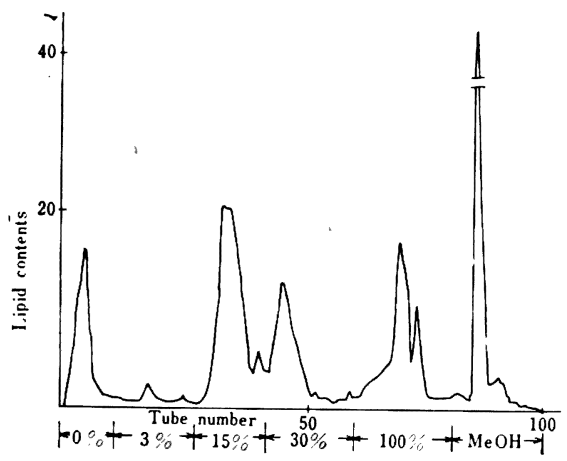

Fig. 2. Separation of phospholipids by silicic

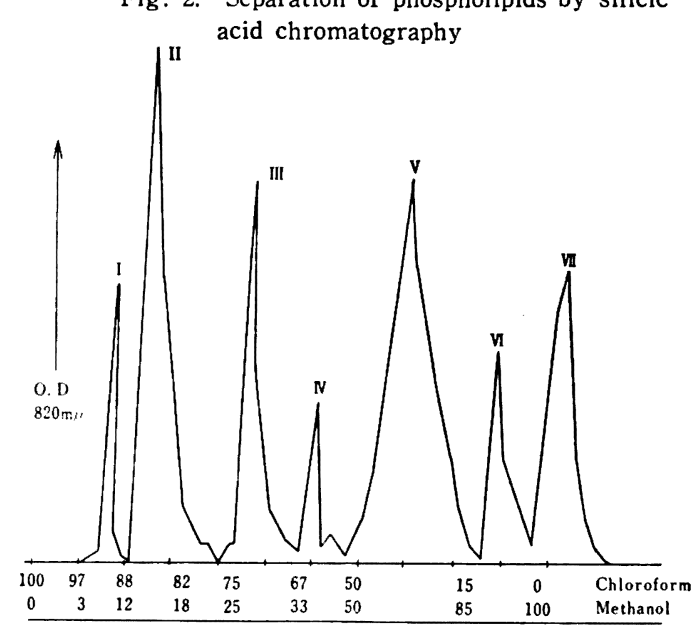

Table 2. Thin-layer chromatography of purple laver phospholipids

$\left(\mathrm{CHCl}_{3}: \mathrm{MeOH}: \mathrm{H}_{2} \mathrm{O}=80: 25: 3\right)$

\begin{tabular}{l|l|l}
\hline & Rf value & Indicator \\
\hline I & 0.92 & Molybdic acid Reagent (t) \\
II & 0.76 & Ninhydrin Reagent (t) \\
$\prime \prime$ & 0.64 (tr.) & Dragendorff Reagent (t) \\
$\prime \prime$ & $0.22($ tr.) & Ninhydrin Reagent (t) \\
Cephalin (standard) & 0.720 .24 & $\prime \prime$ \\
III & 0.25 & $\prime \prime$ \\
IV & 0.43 & Ammoniac silver nitrate Reagent $(+)$ \\
V & 0.40 & Dragendorff Reagent(t) \\
Lecithin (standard) & 0.420 .13 & $\prime \prime$ \\
VI & 0.17 & $\prime \prime$ \\
Sphingomyelin (standard) & 0.18 & $\prime \prime$ \\
VII & 0.12 & $\prime \prime$ \\
Lysolecithin (standard) & 0.11 & $\prime$ \\
\hline
\end{tabular}

ル・水(80:25:3)および(65:25:4) の混合溶媒を用 いて展開し, 発色剤としてはニンヒドリン試薬, ドラー ゲンドルフ試薬, アンモニア性硝酸銀試楽, モリブデン
酸試薬,クロム硫酸試薬などを使用した。ピークIIには 微量のコリン，セリンが混合溶出した。またこのピーク にはクロム硫酸試薬のみで発色したスポットが認められ 
た。リン脂質組成は Table 3 のごとくである。

Table 3. Composition of phospholipids

\begin{tabular}{c|l|r}
\hline \multicolumn{1}{|c|}{ compound } & $(\%)^{*}$ \\
\hline I & Phosphatidic acid & 9.2 \\
II & Phosphatidyl ethanolamine & 30.6 \\
III & Phosphatidyl serine & 14.1 \\
IV & Phosphatidyl inositol & 4.5 \\
V & Lecithin & 23.6 \\
VI & Sphingomyelin & 9.9 \\
VII & Lysolecithin & 13.2 \\
\hline
\end{tabular}

* determined by the amount of phosphorus

5. 脂質の脂助酸組成

アサクサノリより得な総脂質, トリグリセライド, リ ン脂質の脂肪酸を, 塩酸メタノール夜でメチル化しガス クロマトグラフィーにより検索した。結果は Table 4 に 示すごとくである。 $\mathrm{C}_{20: 5}$ 酸が40一55\%と特異的に大きい 值を示した。ついで $\mathrm{C}_{16: 0}$ 酸が20-30\% を占めた。リン 脂質はトリグリセライドに比べ $\mathrm{C}_{20: 5}$ 酸が多く, $\mathrm{C}_{16: 0 \text { 酸 }}$ は少なかった。

Table 4. Fatty acid composition of dried purple laver-lipids

\begin{tabular}{c|r|r|r}
\hline & total lipid & phospholipid & triglyceride \\
\hline- & 0.6 & 0.7 & 0.6 \\
$14: 0$ & 1.6 & 0.5 & 0.8 \\
$15: 0$ & 1.3 & 0.5 & 0.8 \\
$16: 0$ & 25.7 & 18.8 & 28.3 \\
$16: 1$ & 4.1 & 4.5 & 2.8 \\
- & 0.6 & 0.4 & 0.3 \\
$18: 0$ & 1.3 & 1.0 & 0.7 \\
$: 1$ & 4.3 & 3.3 & 3.8 \\
$: 2$ & 2.1 & 2.3 & 2.1 \\
$: 3$ & 0.5 & 0.4 & 0.3 \\
$20: 1$ & 4.4 & 4.2 & 4.4 \\
$: 2$ & 1.0 & 0.8 & 2.4 \\
$: 3$ & 2.9 & 2.1 & 0.7 \\
$: 4$ & 4.5 & 1.1 & 6.4 \\
$: 5$ & 40.8 & 54.9 & 41.1 \\
- & 4.5 & 4.3 & 4.5 \\
\hline
\end{tabular}

YANAGIMOTO GCG-550F

$15 \%$ DEGS (on CELITE 545)

Carrier gas: $\mathrm{N}_{2}$

Column: $2.2 \mathrm{~m}$

Column temp. $175^{\circ} \mathrm{C}$

6. アサクサノリ脂質の抗酸化性

Fig. 3 に示した各区分および不ヶン化物の抗酸化効力 を検討した。抗酸化効力はOlcott ${ }^{\text {3) }}$ らの行なったオーブ
ンテストによった。すなわち基質油にサンプルを一定量 添加し $45^{\circ} \mathrm{C}$ オーブンに入れ酸化誘尊期の終末期にみら れる重量增加までの日数を以て抗酸化性の程度を㭘討し た。基質油は, サフラワー油をケン化し，メチル化後真 空蒸留に上り得たメチルエステルを用いた。Fig. 3 は基 質油に各試料を $0.02 \%$ 添加した際の結果である。II，

Fig. 3. Comparative antioxidant activity of dried purple laver-lipids on the antoxidation of sufflower oil esters (at $45^{\circ} \mathrm{C}$ )

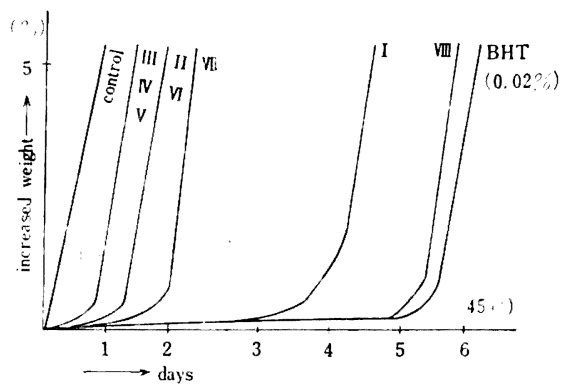

I Total lipids, II unsaponifiable matter, III $n$-hexane fraction, IV $3 \% \mathrm{Et}_{2} \mathrm{O}$ in $n$-hexane fraction, $\mathrm{V} 15 \% \mathrm{Et}_{2} \mathrm{O}$ in $n$-hexane fraction, VI $30 \% \mathrm{Et}_{2} \mathrm{O}$ in $n$-hexane fraction, VII $\mathrm{Et}_{2} \mathrm{O}$ fraction, VIII $\mathrm{MeOH}$ fraction Added $\%$ to substrate: I $(0.05 \%)$, II-VIII $(0.02 \%)$.

III. IV, V, VIには効果がみられない。VIはやや効果が

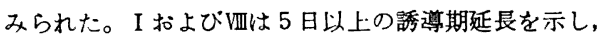
とくにV四は対照として用いた B H T 0.02\% 添加と同程 度の効果を示した。

つぎに各区分のシネルギストとしての効果をみるため 基質油に BHT $0.02 \%$ よび各区分 $0.02 \%$ 添加し同様 な試験を行なった。結果はFig.4 に示すごとくである。

Fig. 4. Comparative effect of dried purple laver-lipids as synergists for BHT in sufflower oil esters (at $45^{\circ} \mathrm{C}$ )

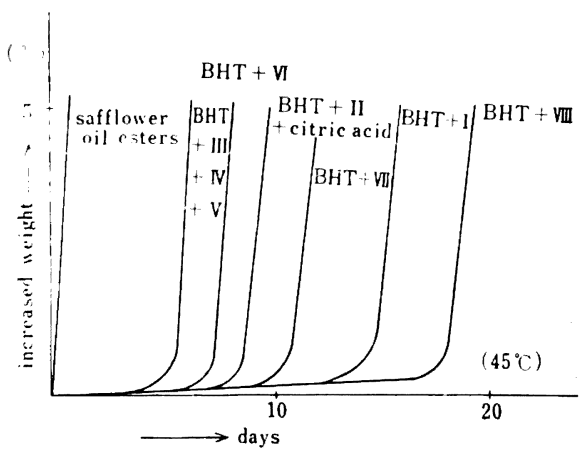


すなわち，III，IV，V，VIに効果がみられない。しか しVにはやや効果がみられた。【は比較試験として行な った BHT0.02\%+クェン酸 $0.02 \%$ と同程度, VII, I , VII はそれよりる大きい効果を示した。とくにV业は前試験と 比較してシネルギスとしての效果す大きいといえる。

7. 乾嬠アサクサノリ中の脂質の存在状態

乾燥アサクサノリのタン白質, 糖類, 脂質を染色し各 成分の組輤中の存在状熊を钼察した。すなわち，ズダン 染色, ベーカーアシドへマチン法, アクロレインシッフ 反応，PAS染色により検索した。その結果 Fig. 5に示す

Fig. 5. Tissue of dried purple laver

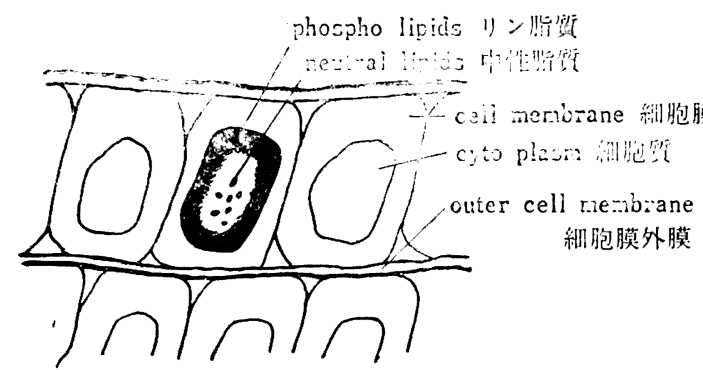

ごとくアサクサノリの細胞質，細胞膜にはいずれも損傷 が認められず，一定の規則正しい配列を保っていること がわかった。また脂質は細胞質にのみ存在し，中性脂質 は紐胞質内に顆粒として存在し，リン脂質は綀胞質内の 周辺部にリング状または馬蹄形をなして存在していた。 そしてこれらの脂質はタン白質および糖類からなる絊胞 膜および糖類よりなる紐胞膜外膜によりかこまれてい、 ることを認めた。このことからアサクサノリの脂質は組 織中で安定な状態で存在していると考えられる。

\section{考察}

以上の結果よりアサクサノリ脂質は $40 \%$ におよぶ 5 酸をふくみ，とくにリン脂質は $50 \%$ 以上の $\mathrm{C}_{20}: 5$ 酸を ふくむことを認めた。このよ5に高度不飽和酸をふくむ にかかわらず，抄憋した乾燥フサクサノリが酸敗臭をお びないのは, 組織学的に見ると脂質が細胞膜外膜, 細胞 膜によりとりかこまれており外気にさらされていないこ

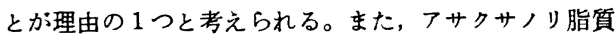
中リン脂質がかなりの抗酸化効力およびシネルギストの 効果を有することを見出した。リン脂質中には，わずか 抗酸化効力を有するすのもあるとされているが，一般に リン脂質はシネルギスとしての効果は有しても，抗酸化 性はないとされている。筆者らの用いたリン脂質区分が リン脂質のみか，あるいはリン脂質以外の成分がふくま れこれが抗酸化効力を示したかについてはなお検討の (248)
余地が残されているよ5に思われる。

総括

アサクサノリにふくまれる脂質の酸化しにくい理由を 明らかにし，市わせてアサクサノリ脂質の組成を知るた め，脂質を分離しその性状を調べたところ，つぎの結果 を得た。

（1）アサクサノリ脂質は $\mathrm{C}_{20}$ : 5 酸に富み，とくにリン 脂質は該酸を $50 \%$ 以上ふくんでいた。

(2) アサクサノリ脂質中トリグリセライドは $25 \%$ ，リ ン脂質は $35 \%$ 程度であった。

(3) リン脂質はホスファチジルェタノールアミン (30.6\%) レシチン $(23.6 \%)$ を主とし，リン脂質 の脂肪酸中 $55 \%$ は土イコサペンタエン酸であった。

(4) アサクサノリの組織を染色し，脂質の存在状態を 調べたところ，脂質は細胞膜外膜および紐胞膜にと りかこまれていた。

(5) リン脂質は対照として用いたBHTと同程度の抗酸

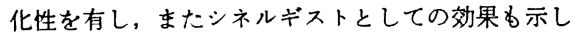
た。

本研究を行な5にあたり，試料を提供された海苔增殖 振興会および染色実験のご指尊を睗わった，東北大学農 学部星野忠彦, 谷内田秀昭の両氏に謝意を表する。

\section{文献}

1）新間, 田口：日水誌， 32，1037-1042（1966）

2) C. Yvonne Shuster, J. R. Froines and H.S. Olcott:J. Am. Oil Chem. Soc., 41, 36-41(1964)

3) H. H. Strain : Biochim.et Biophys. Acta., 109 1-15 (1965)

4) W. D. Harris: ibid., 31, 124-127 (1954)

5) H.S. Olcott and E. Einset: ibid., 35, 161-162 (1957)

6) 蛋白, 核酸酵素「生物化学実験法VII共立出版 (1967)

7）薄層クロマトグラフィー 南山堂: (1960) 